\title{
IDEJNO RJEŠENJE DENIVELACIJE SLAVONSKE AVENIJE U ZAGREBU
}

\section{Kazimir Rehlicki}

ELIPSA-S.Z. d.o.o., Zagreb, dipl.ing.prom, ing.građ., student

\author{
Sanja Dimter \\ Sveučilište J. J. Strossmayera u Osijeku, Građevinski fakultet Osijek, doc.dr.sc.
}

Sažetak: Denivelacije raskrižja u urbanim područjima predstavljaju složene infrastrukturne zahvate koji osim prometnice uključuju i brojne komunalne instalacije. Projektna rješenja prometnih objekata nisu isključivo rezultat prometnih zahtjeva, već na njhovo oblikovanje veliki utjecaj imaju prostorni čimbenici zajedno s komunalnim instalacijama. Budući da se radi o vrlo složenim i skupim infrastrukturnim objektima, prije odluke o izvođenju poželjno je na razumljiv način prikazati širem krugu ljudi projektno rješenje sa svim prednostima i nedostatcima koje ono nosi. U članku je ukratko prikazan sadržaj diplomskog rada u kojem je obrađeno idejno rješenje denivelacije Slavonske avenije u gradu Zagrebu.

Ključne riječi: denivelacija, Slavonska avenija, grad Zagreb, simulacija prometnih tokova, vizualizacija

\begin{abstract}
Reconstruction of existing at-grade intersection into grade separated intersection in urban areas presents complex infrastructural work including other than roads and rearrangement of major utility installations. Road design is not solely the result of traffic demands. Spatial factor together with major utility installations has also great influence to road design. Before decide to build such a complex and expensive infrastructure facility it's necessary to present to a wider range of people designed solution, in an understandable way, with all his advantages and disadvantages. The article briefly presents the contents of the diploma thesis, elaborating conceptual design of grade-separated corridor part of Slavonska Avenue in the city of Zagreb.
\end{abstract}

Key words: grade-separated corridor, Slavonska avenue, city of Zagreb, traffic simulation, visualization 


\section{Uvod}

Prometna mreža grada Zagreba obodno je određena obilaznicom. Postoji više longitudinalnih prometnih pravaca unutar grada, ali oni ili nisu dovršeni, ili ne počinju i ne završavaju na obilaznici, ili nemaju primjeren (konstantan) prometni profil cijelom dužinom. Danas jedino longitudinalni pravac Slavonska avenija, u nastavku Zagrebačka avenija i dalje Ljubljanska avenija, ima konstantan prometni profil i zadovoljavajuće spojeve na prometnu mrežu i obilaznicu grada Zagreba. Međutim, zbog porasta prometa na pojedinim raskrižjima duž Slavonske avenije, nije moguće postići zadovoljavajuću propusnu moć samo povećanjem profila prometnice (dodavanjem prometnih trakova), već se pristupilo razmatranju denivelacije raskrižja.

Idejnim rješenjem obrađena je denivelacija dijela Slavonske avenije sa zonom zahvata od ulice Hrvatske zajednice (HBZ) na istoku do Savske ceste na zapadu. Dužina zahvata iznosi 1.593,88 m.

Složenost zahvata zahtijevala je multidisciplinaran pristup u izradi projektne dokumentacije te je sudjelovalo više projektanata iz različitih tehničkih struka. Idejnim rješenjem napravljen je projekt prometnice, prometna analiza, prometno rješenje, simulacija i vizualizacija prometnih tokova, i dano načelno rješenje komunalnih instalacija.

\section{Postojeće stanje i planovi višeg reda}

U postojećem stanju, u zoni zahvata, Slavonska avenija izvedena je kao gradska avenija s dva kolnika po dva prometna traka, po smjeru vožnje odvojena razdjelnim pojasom. Zonu zahvata određuju denivelirana raskrižja s Ulicom HBZ na istoku i Savskom cestom na zapadu. Unutar zone zahvata nalazi se semaforizirano raskrižje s Marohnićevom ulicom, te manji broj priključaka tipa uljev/izljev sa sjeverne, odnosno Cvjetna cesta i ulaz/izlaz HRT-a s južne strane. Između Marohnićeve ulice i ulice HBZ na južnom kolniku izveden je treći (kontinuirani prometni trak). Na semaforiziranom raskrižju izvedeni su zasebni trakovi za lijevo skretanje te zaseban trak za desno skretanje na istočnom privozu. Postojeće stanje izgrađenosti, položaj i prometna uloga u planiranoj prometnoj mreži prikazani su na slici 1.

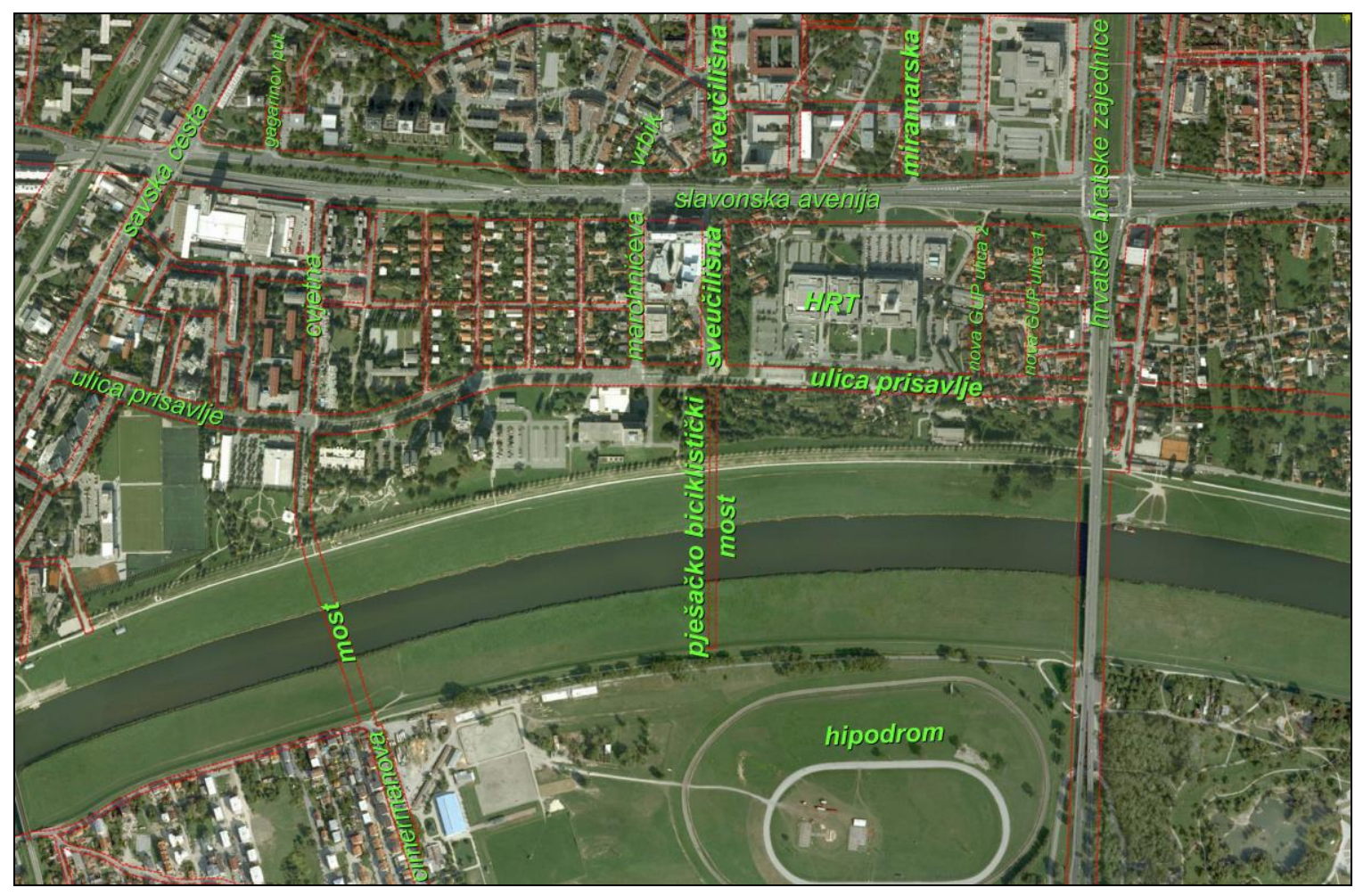

Slika 1 - Postojeće stanje, položaj i prometna uloga u planiranoj prometnoj mreži 
Prema generalnom urbanističkom planu (GUP) grada Zagreba Slavonska avenija je kategorizirana kao gradska avenija s promjenjivom širinom koridora u granicama od 70 do $90 \mathrm{~m}$. Također, GUP-om je, uz postojeća, predviđeno formiranje dodatnih raskrižja s budućim produžetcima postojećih ulica: Miramarska cesta i Sveučilišna aleja. Miramarska cesta i Sveučilišna aleja GUP-om su kategorizirane kao glavne gradske ulice. Produžena Miramarska cesta završava na Slavonskoj aveniji i u prometnom smislu postaje značajna prometnica s funkcijom povezivanja centra i Novog Zagreba (izlaz iz centra grada). Sveučilišna aleja formirana je od Ulice grada Vukovara do ulice Prisavlje, a dalje se preko novoplaniranoga pješačko-biciklističkog mosta preko rijeke Save spaja na prostor sadašnjeg hipodroma. Cvjetna cesta, kategorizirana kao glavna gradska ulica, GUP-om dobiva značajnu prometnu ulogu s funkcijom povezivanja s Novim Zagrebom (od Slavonske avenije, preko Cvjetne ceste i novoplaniranog mosta preko rijeke Save, Ulice Radoslava Cimermana do Avenije Dubrovnik). GUP-om je planirano priključenje dvije nove gradske ulice na zapadni kolnik južne rampe raskrižja Slavonska avenija - ulica HBZ te manji broj prometno nekategoriziranih ulica kojima je ostavljena mogućnost eventualnog priključenja duž sjeverne i južne strane Slavonske avenije.

\section{Prometno opterećenje}

Za potrebe prometne analize obavljeno je brojenje prometa na raskrižju s Marohnićevom ulicom te ulicom HBZ. Rezultati brojenja iskazani prosječnim godišnjim dnevnim prometom prikazani su grafički na slici 2.

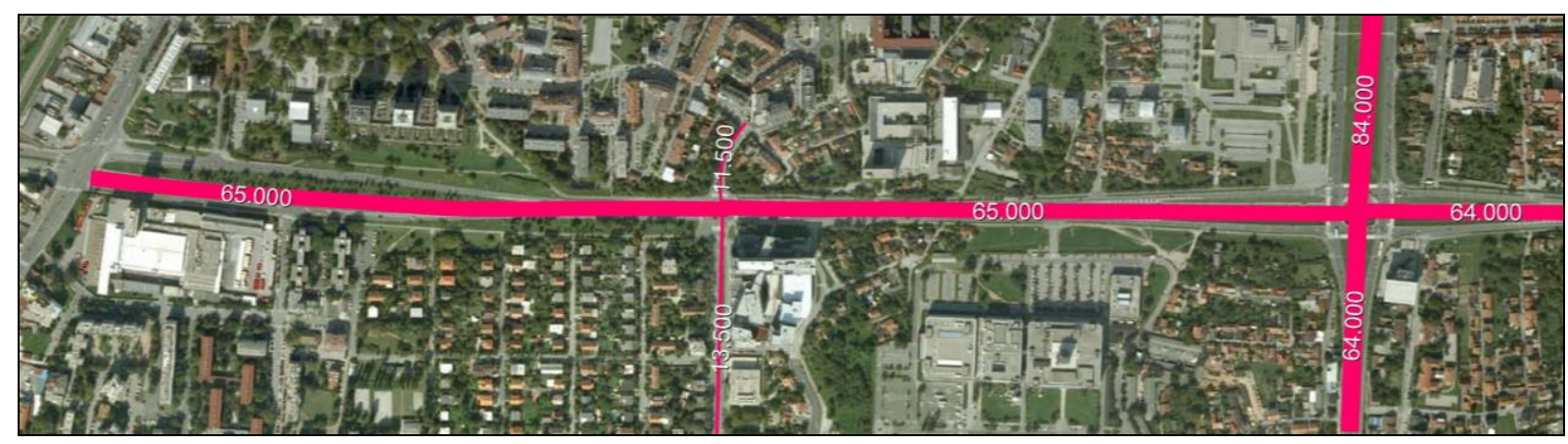

\section{Slika 2 - Postojeće prometno opterećenje, PGDP 2007. godina}

Postojeće stanje na semaforiziranom raskrižju s Marohnićevom ulicom u gornjim vremenskim periodima karakterizira zagušenje i povećani repovi čekanja koji se protežu na susjedna raskrižja. Stupanj zasićenja raskrižja iznosi 1,18 , što ukazuje na $18 \%$ premalu propusnu moć raskrižja. Povećani repovi čekanja u gornjim vremenskim periodima vidljivi su na slici 3.

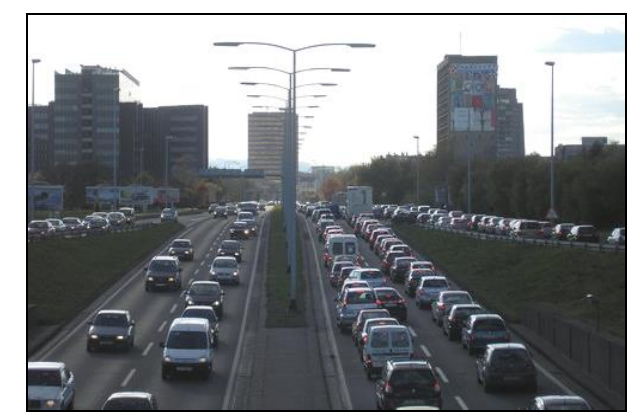

\section{Slika 3 - Pogled s nadvožnjaka ulice HBZ [8]}

Ulazni podatak za prometnu analizu projektnog rješenja, a kasnije i za odabir i dimenzioniranje elemenata prometnice, predstavlja prognoza prometnog opterećenja. Za prognozu prometnog opterećenja utvrđen je trend rasta prometa na temelju brojenja prometa na terenu, prometne studije Grada Zagreba koju je izradila tvrtka 
MWA 1998. godine, a koja predviđa rast prometa po godišnjoj stopi od 2,5 do $3,0 \%$, te broja registriranih motornih vozila na području grada koji raste po godišnjoj stopi od $4,75 \%$.

Prometna studija predviđa rast prometa po godišnjoj stopi od 2,5 do 3,0 \%, uz uvjet da se primarno izgrade infrastrukturni objekti namijenjeni javnom gradskom putničkom prometu čime bi se smanjila potreba za korištenjem osobnih vozila. S obzirom da do danas po tome pitanju nije ništa napravljeno, a od studije je prošlo 10 godina, usvojen je trend rasta prometa po linearnoj stopi od $5 \%$ godišnje za razdoblje od 20 godina.

Iskazano u PGDP-u, prognozirano prometno opterećenje u 2027. godini na razini -1 iznosi 110.000 vozila/dan, a na razini 0 se kreće od 26.000 do 35.000 vozila/dan. Prognozirano prometno opterećenje iskazano kroz PGDP u 2027. godini prikazano je na slici 4.

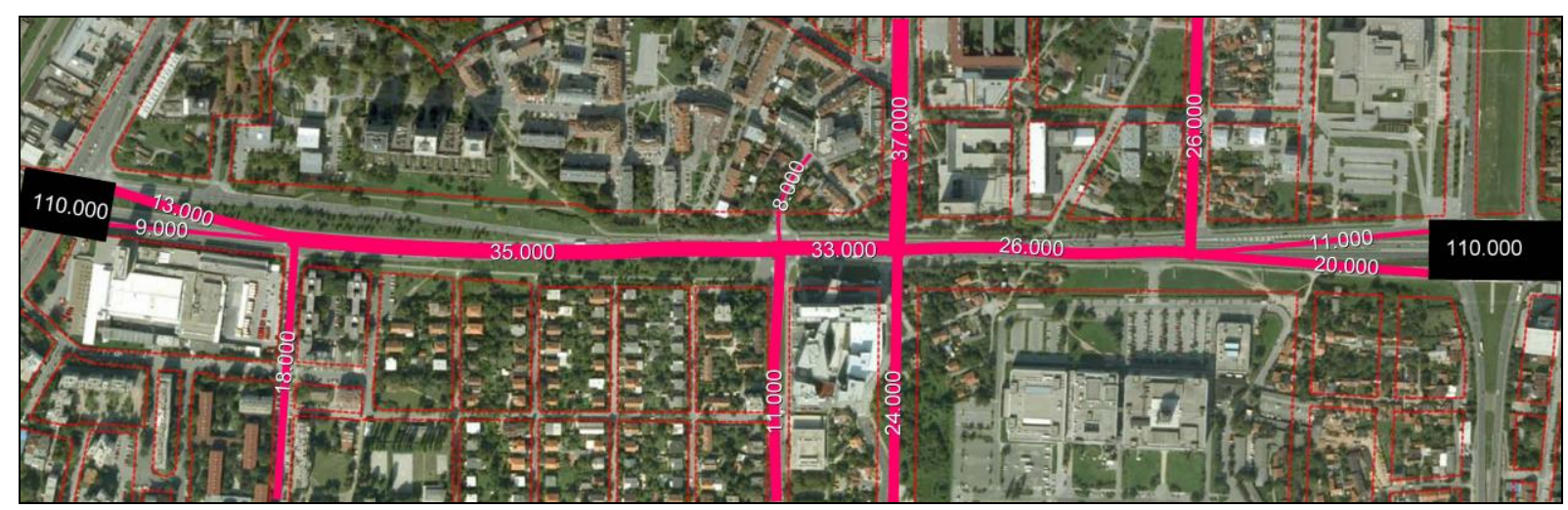

Slika 4 - Prognozirano prometno opterećenje, PGDP 2027. godina

\section{Projektni zadatak}

Idejno rješenje denivelacije temelji se na smjernicama iz projektnog zadatka Odjela za promet i mišljenja Gradskog zavoda za planiranje razvoja grada i zaštitu okoliša. Projektnim zadatkom tražila se rekonstrukcija Slavonske avenije između ulice HBZ i Savske ceste na način da servisni kolnici Slavonske avenije s priključcima ostanu u razini 0, a kolnici Slavonske avenije (glavna trasa) budu u razini -1. Uzdužni presjek postojeće Slavonske avenije s načelom izvođenja denivelacije prema projektnom zadatku prikazan je na slici 5 .

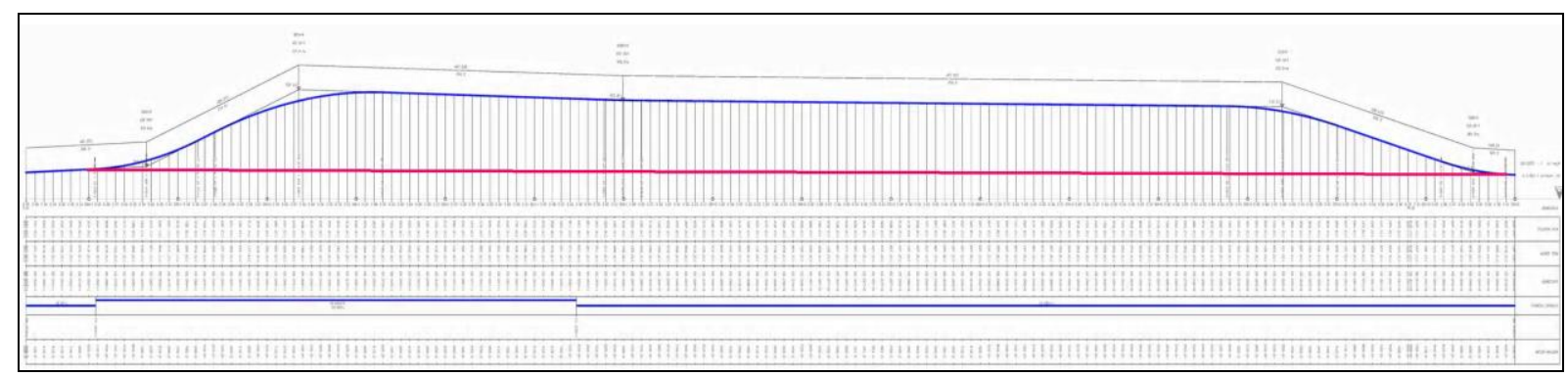

Slika 5 - Uzdužni presjek postojeće Slavonske avenije s načelom izvođenja denivelacije

Pri razmatranju varijanti tipa denivelacije, u obzir su dolazili sljedeći tipovi: kontinuirani nadvožnjak (razina +1 ), kontinuirani podvožnjak (razina -1 otvoreni tip) i tunel (razina -1).

Uvažavajući vizuru koja se otvara pri dolasku preko Mosta slobode iz pravca Novog Zagreba prema središtu grada (zagrebačkoj katedrali), varijanta nadvožnjaka u razini +1 nije dalje razmatrana. Izvođenjem nadvožnjaka u razini +1 bitno bi se narušila vizura grada i stvorila vizualna barijera između Novog Zagreba i središnjeg dijela grada na dužini od cca $2 \mathrm{~km}$. Vizura središnjeg dijela grada, gledano s Mosta slobode, vidljiva je na slici 6. 


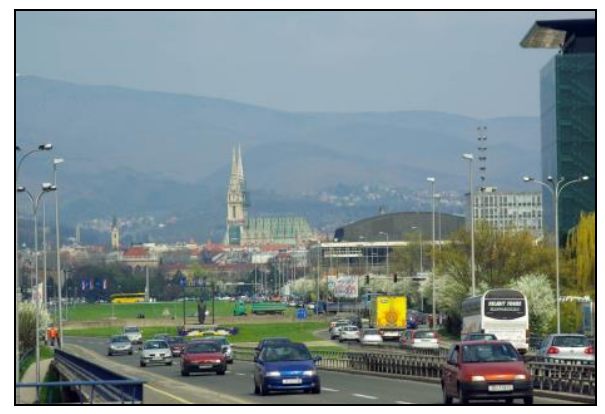

\section{Slika 6 - Vizura grada, pogled s Mosta slobode [9]}

Varijanta kontinuiranog podvožnjaka u razini -1 otvorenog tipa razmatrana je na način da se uz razinu -1 obostrano izvedu servisne prometnice u razini 0 . Na taj način dobio bi se otvoreni središnji prostor iznad razine -1 u širini od $28 \mathrm{~m}$ koji bi predstavljao barijeru između prostora sjeverno i južno od Slavonske avenije. Prostor za formiranje zelenih površina je minimalan te bi prevladavala siva plastičnost betona. Ovisno o odabranom tipu raskrižja - rotor ili četverokrako semaforizirano raskrižje, preko otvorenog središnjeg prostora iznad razine -1 protezale bi se i poprečne prometnice. Budući da se prometnice razine - 1 i razine 0 nalaze jedna pokraj druge (a ne jedna iznad druge), potreban je širi koridor.

Prednosti varijante tunela u razini -1 u odnosu na prethodne dvije varijante su: nema narušavanja vizure grada, potreban je uži koridor jer se prometnice na razini 0 nalaze iznad razine -1 , i omogućava se formiranje znatno većih zelenih površina za hortikulturno uređenje. Nedostatak ove varijante je u troškovima izgradnje i kasnijim većim troškovima tijekom uporabe (troškovi pogona i održavanja prometno sigurnosne opreme tunela).

Idejnim rješenjem razrađena je varijanta tunela u razini -1. Razina -1 izvodi se kao tunel s dvije cijevi. Iznad razine - 1 izvodi se razina 0 koja se spaja na postojeće rampe ulice HBZ i Savske ceste. Na razinu 0 priključuju se produžena Sveučilišna aleja, produžena Miramarska cesta, novi (izmaknuti postojeći) ulaz/izlaz HRT-a, GUP-om novoformirane dvije gradske ulice, nekategorizirana produžena Paromlinska cesta te postojeća Cvjetna cesta, Gagarinov put, Marohnićeva ulica, Vrbik XIII i ceste za pristup parkiralištu Nacionalne sveučilišne knjižnice (NSK). Razina 0 i razina -1 Slavonske avenije povezane su putem rampi. Na raskrižju sa Sveučilišnom alejom izvodi se pješačko biciklistički nathodnik. Idejnim rješenjem denivelacije obuhvaćene su i sve postojeće te planirane komunalne instalacije.

\section{Urbanističko-tehnički uvjeti}

Projektnim rješenjem Slavonska avenija formira se u punoj širini koridora GUP-a u dužini od 1.593,88 m (gledano po osi razine -1).

Razina -1 izvodi se u presjeku s dva prometna traka i zaustavnim trakom. Neposredno prije postojećih podvožnjaka presjek se svodi na dva prometna traka po smjeru bez zaustavnog traka. Razina -1 ima tranzitnu funkciju s osiguranim uvjetima neprekinutog prometnog toka. Spajanje razine -1 i razine 0 omogućeno je preko dva para rampi. Jedine točke kolizije u razini -1 su tipa uplitanje i isplitanje u prometni tok razine -1 , a odvijaju se neposredno prije, odnosno nakon portala tunela. Situacija prometnih površina razine -1 prikazana je na slici 7.

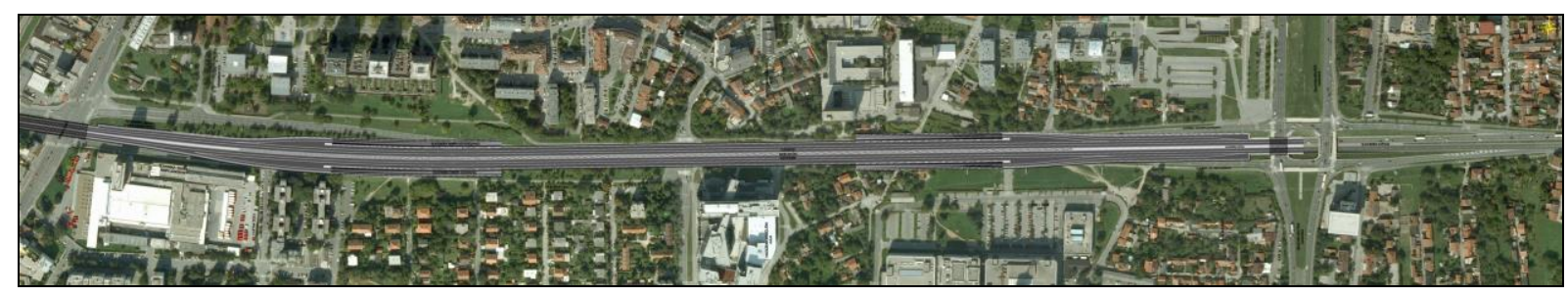

Slika 7 - Situacija prometnih površina razine -1

Rehlicki, K; Dimter, S 
Razina 0 projektirana je $s$ dva prometna traka po smjeru vožnje s dodatnim trakovima za skretanja. Razina 0 je u funkciji opsluživanja prometno značajnih priključnih ulica: Miramarska cesta, Sveučilišna aleja, Marohnićeva ulica, ulica Vrbik XIII i Cvjetna cesta. Sva križanja odvijaju se na razini 0 preko raskrižja tipa rotor i uljev/izljev. Situacija prometnih površina razine 0 prikazana je na slici 8.

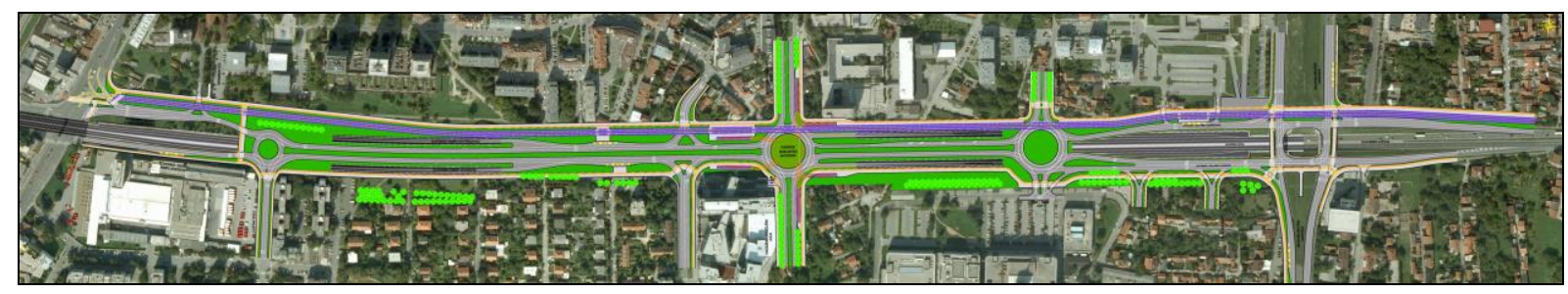

\section{Slika 8 - Situacija prometnih površina razine 0}

Za spoj produžene Miramarske ceste i izmaknutog ulaza/izlaza u HRT predviđeno je dvotračno kružno (roto) raskrižje. Dvotračno roto raskrižje predviđeno je i za spoj produžene Sveučilišne aleje. Zbog značajnog pješačkog i biciklističkog prometa, iznad rotora Sveučilišne aleje predviđen je nathodnik. Marohnićeva ulica i Ulica Vrbik XIII priključuju se preko raskrižja tipa uljev/izljev. Lijeva skretanja posredno su omogućena polukružnim okretanjem na rotorima Sveučilišna aleja i Cvjetna cesta. Cvjetna cesta, kao budući spoj s Novim Zagrebom, na Slavonsku aveniju se spaja preko roto raskrižja na razinu 0. Roto raskrižje je dvotračno za smjer istok-zapad, a jednotračno za skretanje prema jugu i sjeveru. Raskrižje s ulicom Gagarinov put, kao i u postojećem stanju, ostaje tipa uljev/izljev.

Duž cijelog zahvata na Slavonskoj aveniji predviđena je dvosmjerna biciklistička staza i pješački nogostup. Osim na postojećim raskrižjima Savske ceste i ulice HBZ, prijelazi preko Slavonske avenije omogućeni su na raskrižju sa Sveučilišnom alejom preko nathodnika i Cvjetnom cestom preko obilježenog pješačko-biciklističkog prijelaza na kolniku razine 0 . Širina biciklističkog traka iznosi $1,00 \mathrm{~m}$. Dva biciklistička traka međusobno su odvojena zaštitnom širinom od $0,50 \mathrm{~m}$. Očekivan je značajan promet pješaka i biciklista zbog sadržaja u Sveučilišnoj aleji te izgradnje novog pješačko-biciklističkog mosta (hipodrom). Omogućavanjem prijelaza pješaka i biciklista preko Slavonske avenije u razini +1 , formiranjem nathodnika stvara se atraktivna površina iznad roto raskrižja. Arhitektonsko oblikovanje i opremanje nathodnika bit će predmet obrade zasebne projektne dokumentacije.

lako GUP-om i projektnim zadatkom nije predviđena trasa tračničkog sustava duž Slavonske avenije, tijekom razrade projekta i sastanaka s predstavnicima iz raznih gradskih ureda, naknadno je zatraženo da se u idejno rješenje ugradi i tramvajsko tijelo. Trasa tramvaja definirana je sjevernom stranom Slavonske avenije. Tramvajska trasa od Savske ceste na zapadu proteže se prema istoku do ulice HBZ. Stajališta su predviđena kod raskrižja sa Sveučilišnom alejom i na sjevernom platou ispred NSK. Osim tramvajskog, definirana je i trasa javnog gradskog autobusnog prometa. Autobusna stajališta (ugibališta) predviđena su kod raskrižja s Marhonićevom ulicom i ulicom Vrbik XIII, te u zoni raskrižja s ulicom HBZ.

\subsection{Poprečni presjeci, tlocrtni elementi i elementi uzdužnog presjeka}

Nekadašnji prometni pravac Slavonska - Ljubljanska avenija poprečnim presjekom, tlocrtnim i elementima uzdužnog presjeka projektiran je za računsku brzinu od $100 \mathrm{~km} / \mathrm{h}$. Međutim, semaforizacijama raskrižja brzine su ograničene prometnim znakovima na vrijednosti manje od projektirane. Najveća dozvoljena brzina iznosi $80 \mathrm{~km} / \mathrm{h}$ na manjem dijelu poteza (to je uglavnom stari dio na kojem nisu izvođeni zahvati na poprečnom presjeku i nisu fomirana semaforizirana raskrižja). Duž cijele Zagrebačke avenije najveća dozvoljena brzina iznosi $60 \mathrm{~km} / \mathrm{h}$. Na ostalim dijelovima brzina je ograničena na $70 \mathrm{~km} / \mathrm{h}$.

Idejnim rješenjem, odnosno odabirom poprečnog presjeka, tlocrtnih elemenata i elemenata uzdužnog presjeka, usvajaju se računske brzine prikazane u tablici 1. 


\section{Tablica 1 - Mjerodavne brzine}

\begin{tabular}{|l|c|c|}
\hline razina 0 & 50 & $\mathrm{~km} / \mathrm{h}$ \\
\hline razina -1 & 90 & $\mathrm{~km} / \mathrm{h}$ \\
\hline rampe za povezivanje razine 0 i razine -1 & 60 & $\mathrm{~km} / \mathrm{h}$ \\
\hline
\end{tabular}

\subsubsection{Poprečni presjeci}

Postojeća Slavonska avenija i u nastavku nekadašnja Ljubljanska avenija imala je konstantan poprečni presjek od istoka do zapada kroz cijeli grad. Raznim rekonstrukcijama Slavonske avenije došlo je na segmentima do promjene u elementima poprečnog presjeka.

$U$ istočnom dijelu grada (istočno od Savske ceste) postoji tendencija zadržavanja širine prometnog traka od $3,50 \mathrm{~m}$ i rubnog traka širine $0,50 \mathrm{~m}$. Razlog leži u tome što na istočnom dijelu u bližoj prošlosti nije izvođena rekonstrukcija prometnice na način da se proširivala dodavanjem provoznog prometnog traka, niti su se formirala nova raskrižja u razini pa se tako nije ni mijenjao poprečni presjek prometnice. Izvođena su samo obnavljanja habajućeg sloja. Zahvati koji su izvedeni na istočnom dijelu su denivelacije postojećih semaforiziranih raskrižja te se na objektima izvela širina prometnog traka od $3,50 \mathrm{~m}$, a na objektima je i zakonska obveza izvođenja rubnog traka (u ovim slučajevima) širine $0,50 \mathrm{~m}$.

Sredinom 90-ih godina prošlog stoljeća izvedena je denivelacija raskrižja Slavonske avenije i Savske ceste na način da je Slavonska avenija izvedena kao podvožnjak s dva prometna traka u smjeru vožnje širine pojedinog traka $3,00 \mathrm{~m}$ i rubnim trakovima od $0,30 \mathrm{~m}$.

Unatrag pet godina rekonstruirana je Zagrebačka avenija u profil s tri prometna traka u smjeru vožnje širine $3,25 \mathrm{~m}$ i rubnim trakovima od $0,30 \mathrm{~m}$.

Idejnim rješenjem usvojena je širina prometnog traka od $3,50 \mathrm{~m}$ i rubnog traka $0,50 \mathrm{~m}$ za razinu -1 , odnosno $3,00 \mathrm{~m}$ i $0,50 \mathrm{~m}$ za razinu 0 . Normalni poprečni presjek grafički je prikazan na slici 9 , a elementi poprečnog presjeka prometnice razine -1 , razine 0 i rampi za povezivanje razine -1 i 0 navedeni su u tablici 2.

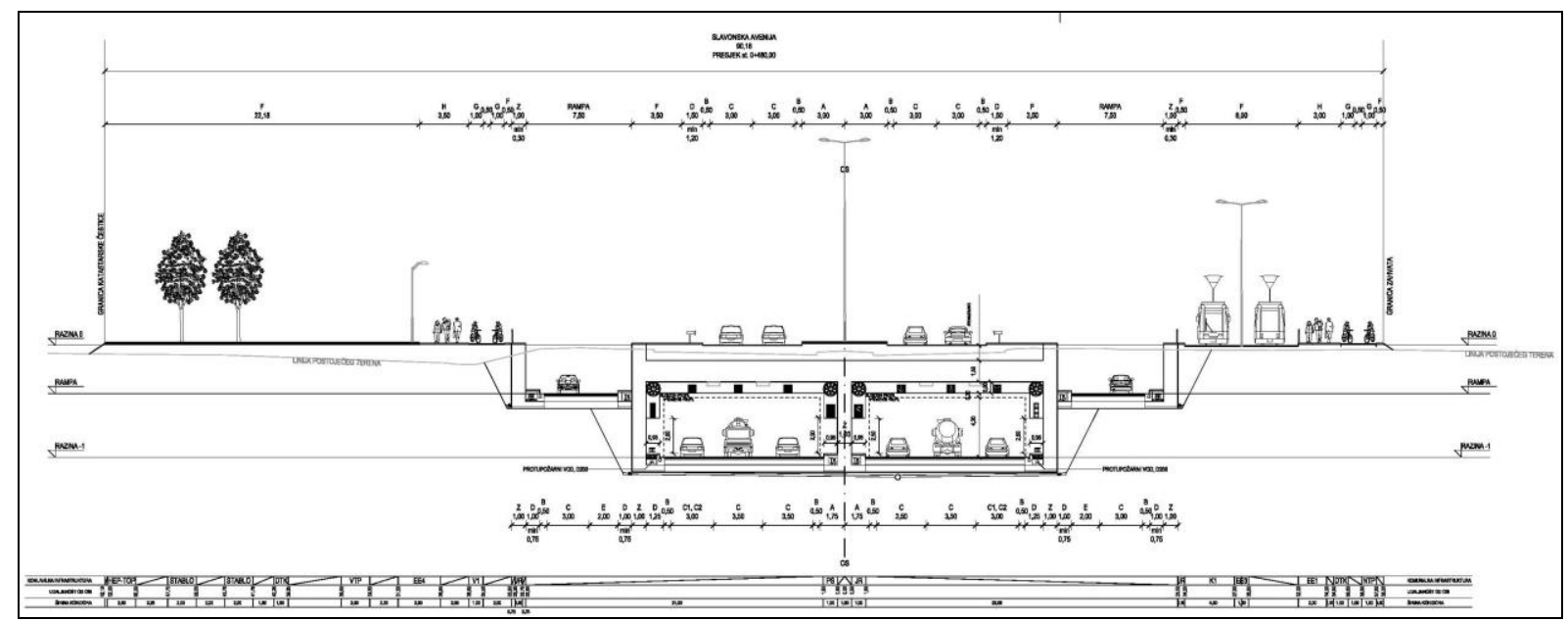

\section{Slika 9 - Normalni poprečni presjek [6]}

Prometni profil tunela iznosi $4,20 \mathrm{~m}$, slobodni profil $4,50 \mathrm{~m}$. Svjetla visina tunelske cijevi iznosi $5,30 \mathrm{~m}$. Kružna raskrižja s Miramarskom cestom i Sveučilišnom alejom su dvotračna, vanjskog polumjera $35,00 \mathrm{~m}$. Kružno raskrižje s Cvjetnom cestom je predviđeno kao "turbo" rotor s dva prometna traka u smjeru istok-zapad i jednim prometnim trakom u smjeru sjever-jug. Vanjski polumjer rotora iznosi $26,00 \mathrm{~m}$. 
Tablica 2 - Poprečni presjek prometnice razina -1 (tunel), razina 0 i rampe za povezivanje razine -1 i 0

\begin{tabular}{|c|c|c|c|}
\hline element presjeka & razina -1 & rampe & razina 0 \\
\hline nogostup - pješačka staza & - & - & $3,00 \mathrm{~m}$ \\
\hline biciklistički trak & - & - & $1,00 \mathrm{~m}$ \\
\hline zaštitna širina & - & - & $0,50 \mathrm{~m}$ \\
\hline biciklistički trak & - & - & $1,00 \mathrm{~m}$ \\
\hline zeleni pojas & - & - & $3,00 \mathrm{~m}$ \\
\hline tramvajsko tijelo & - & - & $8,00 \mathrm{~m}$ \\
\hline zeleni pojas & - & - & $7,50 \mathrm{~m}$ \\
\hline autobusno ugibalište & - & - & $3,50 \mathrm{~m}$ \\
\hline potporni zid & $1,00 \mathrm{~m}$ & - & - \\
\hline servisni prolaz (reviziona staza) & $1,25(0,95) \mathrm{m}$ & - & - \\
\hline rubni trak & $0,50 \mathrm{~m}$ & - & $0,50 \mathrm{~m}$ \\
\hline prometni trak (uljev/izljev rampa) ili zaustavni trak & $3,00 \mathrm{~m}$ & - & - \\
\hline vozni trak & $2 \times 3,50 \mathrm{~m}$ & - & $2 \times 3,00 \mathrm{~m}$ \\
\hline rubni trak & $0,50 \mathrm{~m}$ & - & $0,50 \mathrm{~m}$ \\
\hline servisni prolaz (reviziona staza) & $1,25(0,95) \mathrm{m}$ & - & $1,25(0,95) \mathrm{m}$ \\
\hline razdjelni pojas & - & - & $6,00 \mathrm{~m}$ \\
\hline potporni zid & $1,00 \mathrm{~m}$ & $1,00 \mathrm{~m}$ & - \\
\hline servisni prolaz (reviziona staza) & $1,25(0,95) \mathrm{m}$ & $1,00(0,75) \mathrm{m}$ & - \\
\hline rubni trak & $0,50 \mathrm{~m}$ & $0,50 \mathrm{~m}$ & $0,50 \mathrm{~m}$ \\
\hline vozni trak & $2 \times 3,50 \mathrm{~m}$ & $1 \times 3,00 \mathrm{~m}$ & $2 \times 3,00 \mathrm{~m}$ \\
\hline $\begin{array}{l}\text { prometni trak (uljev/izljev rampa) ili zaustavni trak ili } \\
\text { prometni trak proširenje }\end{array}$ & $3,00 \mathrm{~m}$ & $2,00 \mathrm{~m}$ & - \\
\hline rubni trak & $0,50 \mathrm{~m}$ & - & $0,50 \mathrm{~m}$ \\
\hline servisni prolaz (reviziona staza) & $1,25(0,95) \mathrm{m}$ & $1,00(0,75) \mathrm{m}$ & $1,25(0,95) \mathrm{m}$ \\
\hline potporni zid & $1,00 \mathrm{~m}$ & $1,00 \mathrm{~m}$ & - \\
\hline autobusno ugibalište & - & - & $3,50 \mathrm{~m}$ \\
\hline zeleni pojas & - & - & $7,50 \mathrm{~m}$ \\
\hline biciklistički trak & - & - & $1,00 \mathrm{~m}$ \\
\hline zaštitna širina & - & - & $0,50 \mathrm{~m}$ \\
\hline biciklistički trak & - & - & $1,00 \mathrm{~m}$ \\
\hline nogostup - pješačka staza & - & - & $3,00 \mathrm{~m}$ \\
\hline
\end{tabular}

\subsubsection{Tlocrtni elementi}

Idejno rješenje denivelacije Slavonske avenije položajno je definirano osima prometnica: razina 0 (od rotora na Miramarskoj cesti do rotora na Cvjetnoj cesti), razina -1, rampa ulica HBZ sjeverozapad, rampa ulica HBZ jugozapad, rampa Savska cesta sjeveroistok i rampa Savska cesta jugoistok. Situacije razine 0 i razine -1 na geodetskoj podlozi prikazane su na slikama 10 i 11.

Os razine 0 sastoji se od pravaca međusobno povezanih kružnim lukom polumjera $3.300,00 \mathrm{~m}$ i dužine $273,39 \mathrm{~m}$.

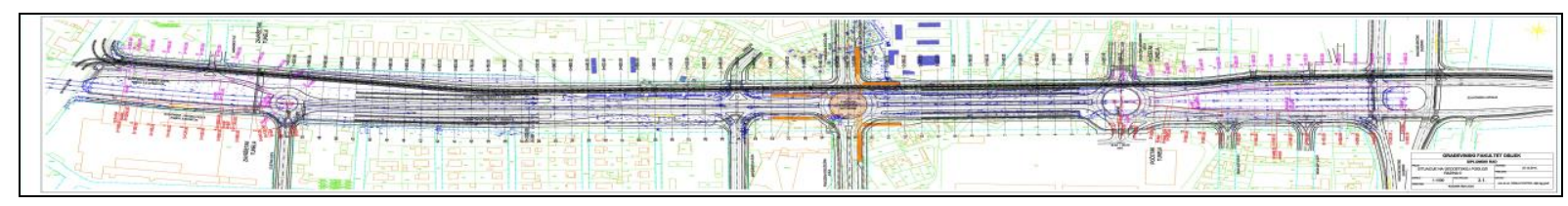

Slika 10 - Situacija razine 0 na geodetskoj podlozi [6] 
Os razine -1 sastoji se od pravaca međusobno povezanih kružnim lukom polumjera $3.300,00 \mathrm{~m}$ i dužine $539,03 \mathrm{~m}$.

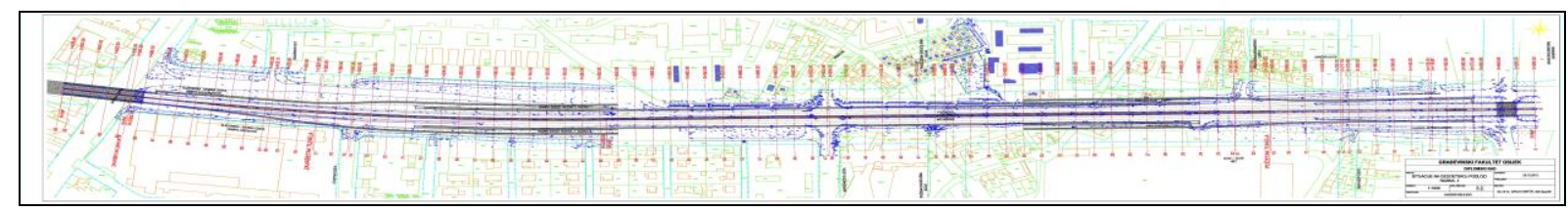

\section{Slika 11 - Situacija razine -1 na geodetskoj podlozi [6]}

Os rampe ulice HBZ sjeverozapad sastoji se od pravaca međusobno povezanih kružnim lukom polumjera $846,50 \mathrm{~m}$ i dužine 116,50 m. Os je postavljena uz lijevi rub kolnika na način da što više prati postojeći kolnik rampe te se ostalim dijelom prilagođava spoju na rotor Miramarske ceste.

Os rampe ulice HBZ jugozapad sastoji se od pravaca međusobno povezanih kružnim lukom polumjera 846,50 m i dužine 130,86 m. Os je postavljena uz desni rub kolnika na način da što više prati postojeći kolnik rampe te se ostalim dijelom prilagođava spoju na rotor Miramarske ceste.

Os rampe Savske ceste sjeveroistok sastoji se od pravaca međusobno povezanih kružnim lukom polumjera $120,00 \mathrm{~m}$ i dužine $68,75 \mathrm{~m}$. Os je postavljena na način da se kolnik od rotora Cvjetna cesta što više prilagodi i uklopi u postojeći kolnik rampe.

Os rampe Savske ceste jugoistok sastoji se od tri pravca međusobno povezana kružnim lukovima polumjera $120,00 \mathrm{~m}$ i 3.250,00 m dužine $34,11 \mathrm{~m}$ odnosno $117,01 \mathrm{~m}$. Os je postavljena na način da se kolnik od rotora Cvjetna cesta što više prilagodi i uklopi u postojeći kolnik rampe.

\subsubsection{Elementi uzdužnog presjeka}

Glavni čimbenik koji uvjetuje definiranje vertikalne geometrije je potok Kuniščak. S obzirom na velike tehničke probleme koji bi se javili pri eventualnom izmiještanju trase i ponovnom visinskom uklapanju potoka Kuniščak u Marohnićevoj ulici, odabrano je rješenje kojim razina -1 Slavonske avenije prolazi ispod potoka Kuniščak. Ovim rješenjem niveleta razine -1 u najnižoj točki nalazi se cca $11 \mathrm{~m}$ ispod razine postojećeg kolnika. Uzdužni presjek sa svim osima prikazan je na slici 12.

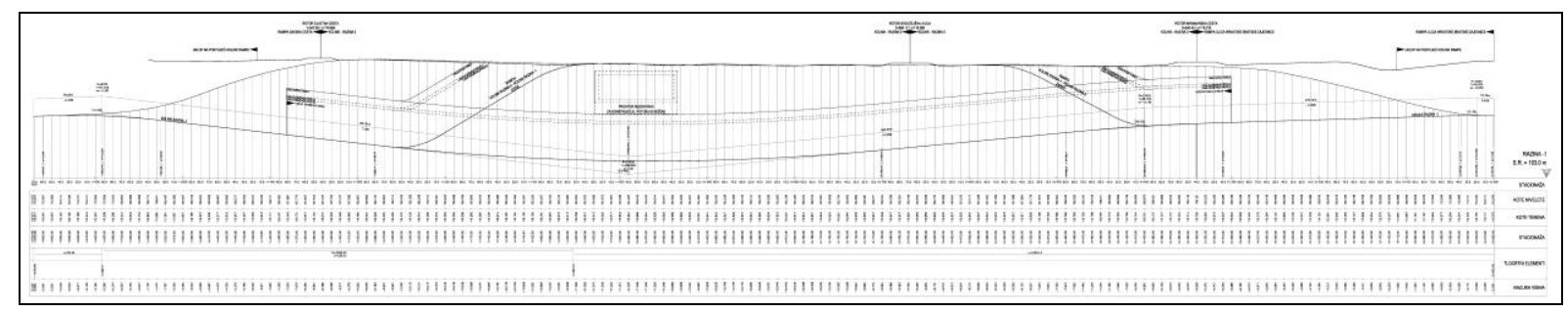

\section{Slika 12 - Uzdužni presjek sa svim osima}

Niveleta razine 0 , od rotora na Miramarskoj cesti do rotora na Cvjetnoj cesti, položena je na način da prati niveletu postojećeg kolnika Slavonske avenije kako bi se zadržala današnja vizura. Niveleta je postavljena uz uzdužne nagibe od minimalno $0,3 \%$ do $0,5 \%$. Odabrani su minimalni nagibi nivelete pod pretpostavkom da će se oborinske vode prikupljati točkasto putem slivnika.

Nivelete sjeverne i južne rampe HBZ-a u potpunosti prate postojeći kolnik rampe. Nakon odvajanja s postojećeg kolnika, rampe se priključuju na rotor Miramarska. Jugozapadna rampa se s postojećeg kolnika rampe spaja na rotor Miramarska cesta uz uspon od $1,5 \%$ na dužini $62,55 \mathrm{~m}$, a zatim pad od $0,3 \%$ na dužini od $118,80 \mathrm{~m}$, uz konkavno zaobljenje polumjerom $2100,00 \mathrm{~m}$, odnosno konveksno zaobljenje polumjerom $1.100,00$ m. Sjeverozapadna se rampa s postojećeg kolnika rampe spaja na rotor Miramarska cesta uz uspon od 2,5\% na dužini $44,568 \mathrm{~m}$, a zatim pad od $0,3 \%$ na dužini od $137,39 \mathrm{~m}$, uz konkavno zaobljenje polumjerom $750,00 \mathrm{~m}$, odnosno konveksno zaobljenje polumjerom 1.100,00 m. 
Nivelete sjeverne i južne rampe Savske ceste u potpunosti prate postojeći kolnik rampe. Od novoprojektiranog rotora na Cvjetnoj cesti uklapaju se na postojeći kolnik rampi. Jugoistočna rampa se s rotora na postojeći kolnik rampe spaja uz uspon od $0,3 \%$ na dužini $19,99 \mathrm{~m}$, a zatim uz pad od $0,3 \%$ na dužini od 33,42 $\mathrm{m}$, uz konveksno zaobljenje polumjerom $3.200,00 \mathrm{~m}$. Sjeveroistočna se rampa s rotora na postojeći kolnik rampe spaja uz uspon od $0,3 \%$ na dužini $21,09 \mathrm{~m}$, a zatim uz pad od $0,3 \%$ na dužini od $27,61 \mathrm{~m}$, uz konveksno zaobljenje polumjerom $5.200,00 \mathrm{~m}$. Dalje nivelete obje rampe u potpunosti prate postojeći kolnik rampi.

Niveleta razine -1, od uklopa na niveletu Slavonske avenije ispod ulice HBZ, spušta se uz nagib od $0,3 \%$ na dužini od $379,72 \mathrm{~m}$, a zatim se i dalje spušta uz nagib od 0,95\% na dužini od 590,84 m, kako bi se u zoni potoka Kuniščak postigla dovoljna visina za slobodni profil u zoni ispod potoka. Lom nivelete zaobljen je konveksnim polumjerom od 27.600,00 m. Dalje se niveleta uspinje uz nagib od 1,15\% na dužini $601,91 \mathrm{~m}$ i uklapa na postojeću niveletu ispod Savske ceste. Lom nivelete na uklopu HBZ zaobljen je konveksnim polumjerom od $5.200,00 \mathrm{~m}$, a na uklopu Savske ceste zaobljen je konveksnim polumjerom od 8.700,00 m.

Razina 0 i razina -1 Slavonske avenije spajaju se rampama Slavonska istok i Slavonska zapad. Nagibi rampi određeni su niveletama razine 0 i razine -1 , odnosno položajem potoka Kuniščak i roto raskrižja na razini 0. Rampe istok povezuju razine -1 i razine 0 uz uzdužni nagib 5,3\% na dužini od 135,66 m, uz konkavni polumjer zaobljenja od 750,00 m na spoju s razinom -1 i konveksni polumjer zaobljenja od 1.100,00 m na spoju s razinom 0. Rampe zapad povezuju razinu 0 i razinu -1 uz uzdužni nagib $6,0 \%$ na dužini od $160,61 \mathrm{~m}$ uz konveksni polumjer zaobljenja od 1.100,00 m na spoju s razinom 0 i konkavni polumjer zaobljenja od 750,00 m na spoju s razinom -1 .

\section{Simulacija i vizualizacija prometnih tokova}

Za idejno rješenje denivelacije napravljena je simulacija i vizualizacija odvijanja prometnih tokova korištenjem mikroskopskog simulacijskog modela. Mikroskopski simulacijski model omogućio je analizu prometnog toka, uvažavajući pritom građevinski oblik prometnice (prostor), strukturu prometnog toka, prometne upravljačke uređaje i signale (semafore), te vizualizaciju idejnog rješenja na budućoj (planiranoj) prometnoj mreži u stvarnom vremenu. Mikroskopski simulacijski model bazira se na analiziranju prometnih situacija u vremenskim intervalima.

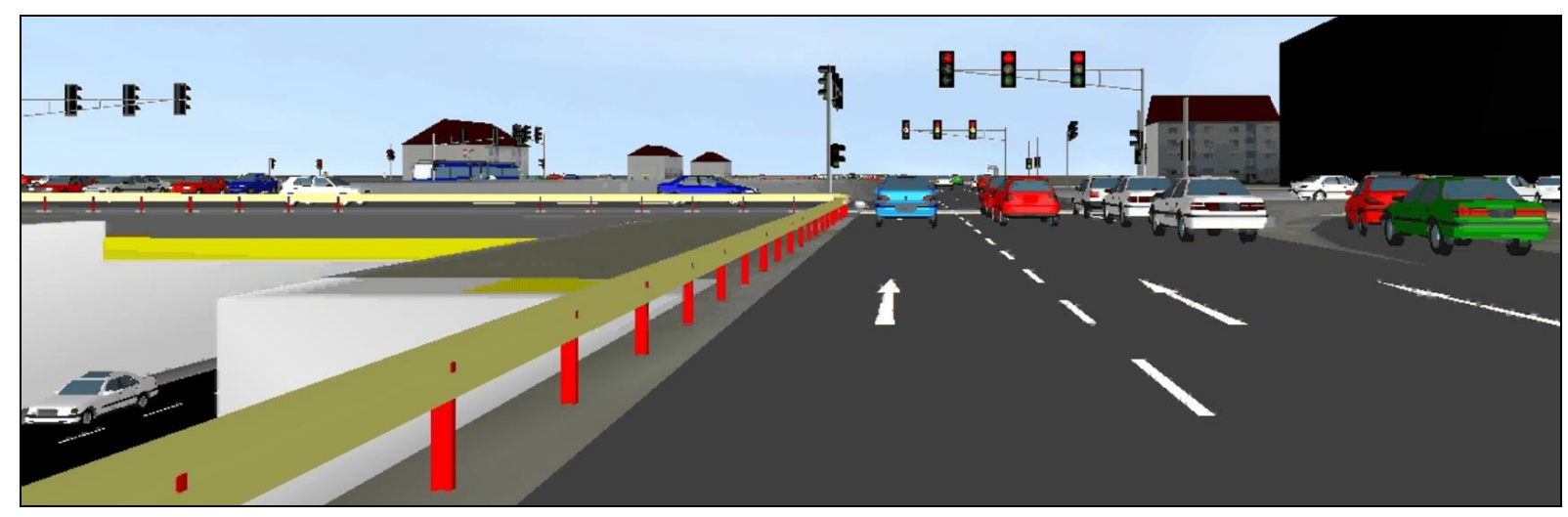

\section{Slika 13 - Pogled vozača pri dolasku na raskrižje s ulicom HBZ}

Prometne situacije određene su prostorom (građevinskim rješenjem prometnice), tehničkim karakteristikama vozila od kojih se sastoji prometni tok, prometnim opterećenjem i psihofizičkim osobinama vozača. Uzimajući u obzir psihofizičke osobine vozača i međuutjecaj položaja vozila u odnosu na ostala vozila, raskrižja, upravljačke uređaje i slično, u kratkim vremenskim intervalima stvara se nova prometna situacija. Nizom od početne do krajnje prometne situacije stvara se niz prometnih slika te se dobiva vizualizacija u stvarnom vremenu.

Za simulaciju i vizualizaciju idejnog rješenja korišten je njemački software paket VISSIM. Navedeni software se nalazi među vodećim svjetskim programskim alatima za izradu mikroskopskih simulacija prometa i prostora. Pojedinačno simulira i opisuje kretanje i ponašanje u realnom vremenu pojedinih sudionika prometnog procesa: 
pješaka, biciklista, motornih vozila, šinskih vozila, zrakoplova i plovila. Zato je pogodan alat za inženjere koji žele simulirati različita građevinska i prometna rješenja prije njihove primjene. Grafički prikazi na slikama 14, 15, 16 i 17 rezultat su korištenja ovog programa.

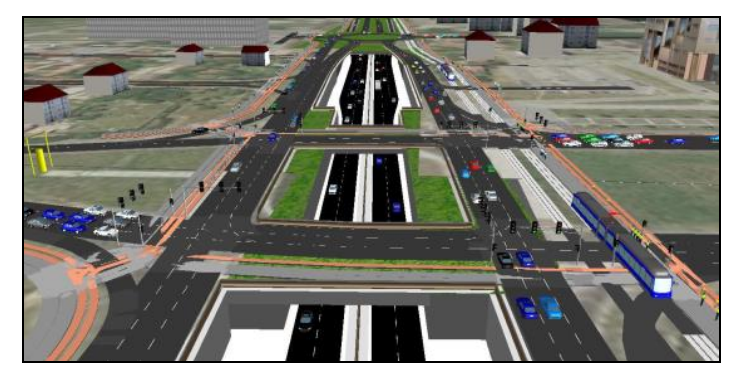

Slika 14 - Pogled od ulice HBZ prema zapadu [5]

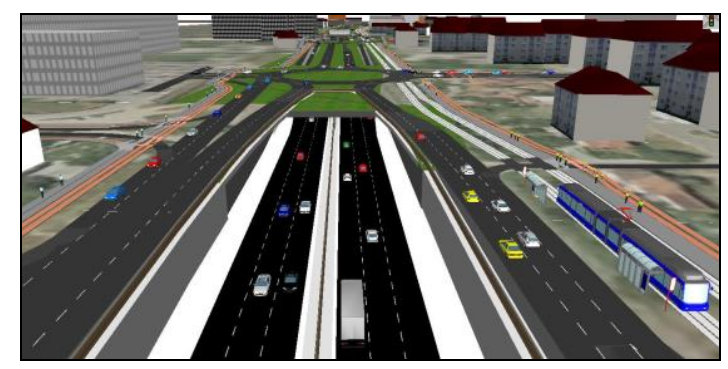

Slika 15 - Portal tunela i kružni tok prometa na produženoj Miramarskoj cesti, pogled od ulice HBZ [5]

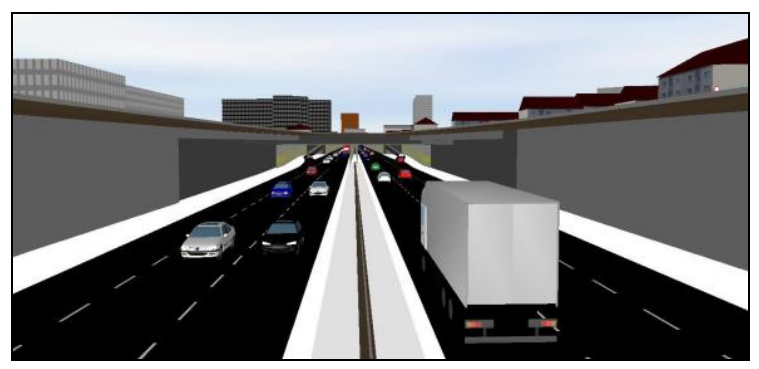

Slika 16 - Razina -1, pogled od ulice HBZ na portal tunela [5]

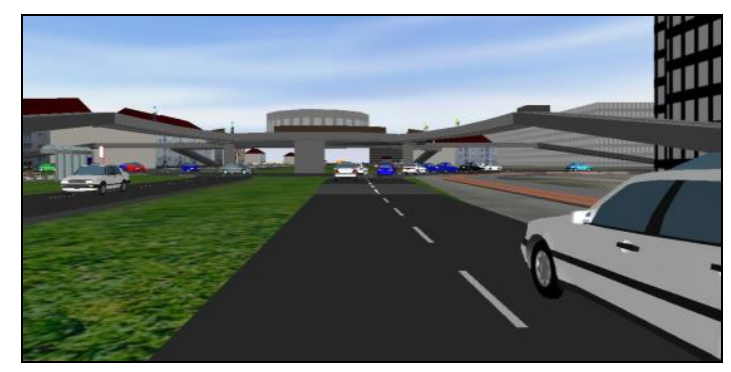

Slika 17 - Pogled vozača pri dolasku do Sveučilišne aleje [5]

\section{Oprema tunela}

Sigurnost u tunelima zahtijeva brojne mjere koje se, između ostalog, odnose na građevinske (projektne) elemente tunela, sigurnosnu opremu, uključujući prometne znakove, upravljanje prometom, obuku hitnih službi, postupke u 
slučajevima nesreća, davanje informacija korisnicima o najboljem načinu ponašanja u tunelima i bolju komunikaciju između odgovornih tijela i hitnih službi kao što su policija, vatrogasci i spasilačke ekipe. Idejnim rješenjem obrađena je elektroenergetika i javna rasvjeta, svjetlotehničko rješenje i ventilacija, hidrantska mreža, odvodnja, prometna oprema: cestovne oznake, sustav nadzora: mjerni i upravljački uređaji, sustav video nadzora i cestovne upravljačke stanice.

\section{Komunalne instalacije}

Izvođenjem denivelacije (spuštanjem u razinu -1 i izvođenjem tunela), zapravo dolazi do podjele avenije na sjeverni i južni dio. Sukladno tome, postojeće instalacije izmiču se izvan profila tunela, izvode se prijelazi s jedne na drugu stranu i po potrebi paralelne instalacije duž sjeverne i južne strane Slavonske avenije. Unutar koridora osigurani su pojasevi raznih širina za polaganje vodova komunalnih instalacija.

Osim potoka Kuniščak, duž cijele trase ispod sjevernog kolnika nalazi se kanalizacijski kolektor profila $400 / 333 \mathrm{~cm}$ te veći broj kanala manjeg profila. Duž cijele trase, u razdjelnom pojasu, položen je magistralni vodovod te veći broj cijevi manjeg profila. Od ostalih instalacija položeni su visokotlačni, srednjetlačni, niskotlačni plinovodi, vrelovod, instalacije elektroenergetike i telekomunikacija.

Najveći zahvat na kanalizaciji odnosi se na izvedbu novog kolektora dimenzije 400/333 cm, dužine cca $1380 \mathrm{~m}$, u predviđenom koridoru sjeverno od trase tunela. Na novi kolektor izvest će se spojevi postojeće kanalizacije sjeverno od Slavonske avenije, na mjestima njihovih križanja. Potrebno je ukloniti cca $1200 \mathrm{~m}$ glavnog kolektora dimenzije $400 / 333 \mathrm{~cm}$, te dio priključnih kanala (cca $400 \mathrm{~m} \phi 40 \mathrm{~cm}, 25 \mathrm{~m}$ dimenzije $60 / 90 \mathrm{~cm}$, $25 \mathrm{~m}$ dimenzije $80 / 120 \mathrm{~cm}, 170 \mathrm{~m}$ dimenzije $100 / 150 \mathrm{~cm}$ te $30 \mathrm{~m}$ dimenzije 160/140).

Najznačajnija instalacija vodoopskrbe je magistralni vodovod $\phi 1000$ (800) mm u pravcu istok-zapad, smješten približno u sredini koridora. Zbog izvedbe tunela potrebno je izmjestiti magistralni vodovod ukupne dužine cca $1230 \mathrm{~m}$ (230 m ф800 mm, te $1000 \mathrm{~m} \phi 1000 \mathrm{~mm})$.

Postojeći visokotlačni plinovod (VTP), položen južnom stranom Slavonske avenije, u pravilu zadržava svoj koridor, osim na mjestima gdje ga je zbog izgradnje tunelskih zidova, a zbog sigurnosnih (zaštitnih) razmaka, potrebno izmjestiti.

Denivelacijom Slavonske avenije formiraju se nove trase distribucijsko telekomunikacijske kanalizacije (DTK). Za prometne sustave osiguran je koridor duž osi na razini 0.

Duž južne strane Slavonske avenije izgrađen je vrelovod. Denivelacijom Slavonske avenije u pravilu se zadržava postojeća trasa, osim na mjestima gdje je neophodno izmiještanje na način da se zaobiđe prepreka te se zatim vrati na postojeću trasu.

\section{Zaključak}

Današnji problemi odvijanja cestovnog prometa u gradovima zahtijevaju multidisciplinaran pristup u njihovu rješavanju. Arhitektonski pristup ima osnovni cilj osiguranje održivog (planskog) razvitka i oblikovanje (definiranje) prostora. Osnovni ciljevi građevinskog (prometnog) pristupa su dimenzioniranje i oblikovanje prometnih objekata. Prometni pristup nastoji osigurati zadovoljavajuće propustne moći te organizaciju prometnih tokova. Instalaterski pristup, pod kojim se razumijevaju sve ostale inženjerske struke, treba riješiti problematiku komunalnih instalacija. lako se prvenstveno radi o prometnici kao površini namijenjenoj kretanju vozila, pješaka i biciklista, česta su ograničenja tzv. neprometnog karaktera koja utječu na konačno oblikovanje prostornih elemenata. Stoga, rješenje prometnice, a prometnica je zapravo jedini objekt koji korisnici uočavaju, u određenim slučajevima ne predstavlja idealno rješenje $s$ gledišta odvijanja prometnih tokova, već kompromis između raznih, često suprotstavljenih ciljeva pojedinih struka.

Denivelacijom Slavonske avenije i izvođenjem tunela omogućava se priključak planiranih glavnih gradskih ulica Sveučilišne aleje i Miramarske ceste na Slavonsku aveniju, izgradnja tračničkog sustava i formiranje kvalitetnih pješačko-biciklističkih površina, uz istovremeno zadovoljavanje prometne potražnje za ciljnu 2027. godinu iskazanu kroz PGDP na razini -1 od 110.000 voz/dan, a na razini 0 od 35.000 voz/dan, a da se pritom ne narušava vizura postojećeg urbanog prostora. 
Danas inženjeri na raspolaganju imaju snažne software alate za projektiranje, a isto tako i za izradu simulacijskih modela i vizualizacija. Vrednovanje i uspoređivanje može se vršiti sa svih motrišta inženjerskih struka: urbanističkih, građevinskih, prometnih i instalaterskih. Primjenom simulacijskih modela omogućava se vrednovanje i uspoređivanje različitih varijanti i scenarija pri traženju najboljeg (optimalnog, građevinski i financijski održivog) rješenja, te utjecaj koji predloženo rješenje ima na postojeću i/li planiranu prometnu mrežu na mjerljiv, odnosno usporediv način kroz kvalitativne pokazatelje.

Uz simulacijski model nezaobilazna je i primjena vizualizacije projektnog rješenja koja bi trebala, osim stručnim krugovima, na jasan način prikazati širem krugu sudionika (javnosti) namjeravani zahvat u prostoru sa svim njegovim prednostima i nedostatcima.

\section{Literatura}

[1] Božičević, I.; Legac, l.: Cestovne prometnice, Fakultet prometnih znanosti Sveučilišta u Zagrebu, 2001.

[2] Korlaet Ž.: Uvod u projektiranje i građenje cesta, udžbenik, Građevinski fakultet Sveučilišta u Zagrebu, 1994.

[3] Korlaet, Ž.: Čvorišta, skripta, Građevinski fakultet, Zagreb, 1995.

[4] Tollazzi, T.: Kružna raskrižja, IQ PLUS d.o.o., 2007.

[5] Lanović, Z:; Rehlicki, K.: Opisivanje i vizualizacija prometnog toka primjenom simulacija, Suvremeni promet, Zagreb, Vol. 28 (2008) 6, str. 451-455.

[6] Elipsa-S.Z. d.o.o.: IDEJNO RJEŠENJE REKONSTRUKCIJE SLAVONSKE AVENIJE SA SPUŠTANJEM NA RAZINU -1, PS-14-2007, Zagreb, 2007.

[7] Rehlicki, K: IDEJNO RJEŠENJE DENIVELACIJE SLAVONSKE AVENIJE U ZAGREBU od Ulice Hrvatske bratske zajednice do Savske ceste, diplomski rad, Građevinski fakultet Osijek, Osijek, 2010.

[8] www.panoramio.com/photo/9461988

[9] www.panoramio.com/photo/20886699 